\title{
KONSEP PENGEMBANGAN DIRI DALAM MENGHADAPI PERKEMBANGAN TEKNOLOGI KOMUNIKASI ERA 4.0
}

\author{
Muhammad Aminullah ${ }^{1,2}$ Marzuki Ali $^{3}$ \\ 1. Dosen Institut Agama Islam (LAI) Al-Aziziyah, Samalanga, Bireuen, Aceh - Indonesia \\ 2. Peneliti pada ICNS-ALAMTOLOGI, 53300 Setapak, Kuala Lumpur, Malaysia \\ 3. Dosen Institut Agama Islam (LAI) Al-Aziziyah, Samalanga, Bireuen, Aceh - Indonesia \\ Email. ${ }^{1}$ aminullahtengku@gmail.com, ${ }^{3}$ marzukiali@iaialaziziyah.ac.id
}

\begin{abstract}
This study is important to explain about self-development in facing the development of communication technology in the 4.0 era. It is proven that the development of communication technology can change communication patterns in human life. But humans should not be controled by technology, but humans basically as controler. The problem is where is the human position in the development of communication technology. This concept needs to be understood so that we do not get traped in the development of communication technology in the 4.0 era. This research uses ethnometodology method to find forms of self-readiness in facing communication technology development. Data collected through observation, documentation and literature review, then analyzed the documentation. This study uses the naturaltology communication approach, to explain the relationship of communication formed in oneself with the development of communication technology. The results explain that self-development becomes the potential and self-readiness that must be possessed by every human being in the face of the development of communication technology. The development of communication technology can classify humans in two positions, namely technology coaches or technology consumers. Adjustment to the position as consumers can deliver us to easy and practical communication, such as the benefits of the internet, smartphones, television and so on. The development of communication technology is a global development that cannot be stoped or anticipated. Humans need to adapt themselves to technological developments, so they can understand it.
\end{abstract}

Keywords: personal development, technology, communication.

Muhammad Aminullah dan Marzuki Ali 1 
Komunike, Volume XII, No. 1 Juni 2020

\begin{abstract}
Abstrak
Kajian ini penting untuk menjelaskan tentang pengembangan diri dalam menghadapi perkembangan teknologi komunikasi era 4.0. Terbukti bahwa perkembangan teknologi komunikasi dapat mengubah pola komunikasi dalam kehidupan manusia. Namun manusia tidak boleh diatur oleh teknologi, tetapi manusia pada hakikatnya sebagai pengatur teknologi. Permasalahannya dimanakah posisi manusia dalam perkebangan teknologi komunikasi. Konsep ini perlu dipahami supaya kita jangan terjebak dalam perkembangan teknologi komunikasi di era 4.0 tersebut. Penelitian ini menggunakan metode etnometodologi untuk menemukan bentuk tindakan kesiapan diri dalam menghadapi perkembangan teknologi komunikasi. Data dikumpulkan melalui pengamatan, dokumentasi dan telaah kepustakaan, selanjutnya dianalisis terhadap dokumentasi tersebut. Kajian ini menggunakan pendekatan komunikasi alamtologi, untuk menjelaskan hubungan komunikasi yang terbentuk pada diri sendiri dengan perkembangan teknologi komunikasi. Hasilnya menjelaskan bahwa pengembangan diri menjadi potensi dan kesiapan diri, yang harus dimiliki oleh setiap manusia dalam menghadapi perkembangan teknologi komunikasi. Perkembangan teknologi komunikasi dapat mengelompokkan manusia pada dua posisi, yakni pembina teknologi atau konsumen teknologi. Penyesuaian diri pada posisi sebagai konsumen dapat menghantarkan kita kepada mudah dan praktis dalam melakukan komunikasi, seperti manfaat internet, manfaat smartphone, televisi dan sebagainya. Perkembangan teknologi komunikasi merupakan suatu perkembangan global yang tidak bisa dibendungi atau diantisipasi. Manusia perlu melakukan penysuaian diri terhadap perkembangan teknologi, supaya dapat memahaminya.
\end{abstract}

Kata kunci: Pengembangan diri, teknologi, komunikasi. 
Komunike, Volume XII, No. 1 Juni 2020

\section{PENDAHULUAN}

Pengembangan diri merupa-kan suatu upaya seseorang dalam meningkatkan daya saing hidup. Pengembangan diri akan mengarahkan manusia untuk menciptakan peradaban. Proses lahirnya sebuah peradaban didasari oleh nilai budaya yang tinggi. Pencipta budaya adalah para intelektual yang didasari oleh pengembangan ilmu dengan benar.

Disisi lain perkembangan teknologi merupakan sebuah tantangan yang tidak bisa dihentikan dalam kehidupan manusia. Dalam hal ini perkembangan teknologi harus bisa dimanfaatkan dengan cara yang cerdas, sehingga menjadi alat bagi kita dalam mengembangkan potensi diri. Dalam hal ini perlu dipahami dalam kehidupan ini kita tidak perlu menentang diri terhadap perkembangan teknologi khususnya dalam bentuk teknologi komunikasi. Namun disini dituntut kita untuk bisa memanfaatkan teknologi komunikasi secara cerdas. Walaupun perkembangannya semakin hari semakin canggih.
Perkembangan teknologi sebenarnya pembuktian daripada hasil perkembangan pemikiran manusia. Oleh karena itu, kehidupan manusia akan terkurung dalam dua ranah yaitu pembangun teknologi dan pengguna teknologi. Pembangun teknologi perupakan kelompok yang membentuk pengguna teknologi sebagai konsumennya. Oleh karena itu, kehidupan kelompok pengguna teknologi secara berkelanjutan pasti diatur oleh teknologi itu sendiri. Maka kelompok konsumenteknologi pasti mengeluarkan pernyayaan bahwa teknologi menjadi pengubah model kehidupan manusia. Sedangkan pembangun teknologi pasti berfikir dan mengkonsepkan kearah mana alur kehidupan manusia ditujukan.

Adapun di sisi lain, manusia yang terkelompok sebagai konsumen semata, juga harus mampu juga untuk memngikuti perkembangan teknologi yang telah dibangunkan. Jika menolaknya, sungguh pasti kehidupan yang dilalui semakin serba teknologi, 
maka semakin terkurung dalam ranah lingkungan yang terbentengi dengan perkembangan teknologi. Oleh karena itu, kehidupan sekarang ini serba dituntut untuk dapat menguasai sistem teknologi. Dengan demikian, perkembangan komunikasi juga berjalan seiring dengan perkembangan teknologi. Perkembangan komunikasi tidak mungkin berseberangan dengan perkembangan teknologi. Hal ini membuktikan perkembangan teknologi adalah sebuah perkemba-ngan yang dapat mengatur kehidupan manusia menjadi semakin mudah dan semakin solid. Oleh karena itu, komunikasi merupakan kebutuhan utama bagi manusia, maka perkembangan teknologi dalam komunikasi menjadi satu keharusan yang wajib terbentuk dalam proses kehidupan manusia. ${ }^{1}$ Perkembangan inilah akhirnya disebut

\footnotetext{
1 Muhammad Aminullah, Theory of Alamin: A Formation of Universal Communication Formula, Budapest International Research and Critics InstituteJournal (BIRCI-Journal) Volume 1 No. 2, June 2018 , (www.bircujournal.com/index.php/birci ) h. 174 2 Muhammad Aminullah, Formula Alamin: Alamtologi Communication, Budapest
}

dengan perkembangan teknologi komunikasi.

Seiring dengan perkemba-ngan teknologi komunikasi, maka dalam hal ini orang yang berilmu dalam mengembangkan potensi diri harus bisa menfaatkan perkemba-ngan teknologi komunikasi sebagai alat ataupun sebagai media dalam mengembangkan ilmunya. ${ }^{2}$ Dulu ilmuan hanya bisa mengembangkan ilmunya hanya menggunakan metode lisan dan tulisan pada media cetak. Namun sekarang ilmuan sudah bisa mengembangkan ilmunya melalui internet yang daya layarnya bisa dicapai seluruh dunia.

Pembahasan ini penulis perlu mejelaskan secara jelas tentang bagaimana perkembangan teknologi komunikasi menjadi manfaat dalam pengembangan diri. Sehingga dapat menemukan fungsi perkembangan

\footnotetext{
International Research and Critics InstituteJournal (BIRCI-Journal) Volume 1 No. 4, December 2018, (www.bircujournal.com/index.php/birci ) h. 51, Lihat juga, Muhammad Aminullah, Komunikasi Alamtologi-ALAMIN, Jilid I, (Kuala Lumpur: Nature Pattern Resources Sdn. Bhd, Cet. 1, 2018) h. 467
} 
Komunike, Volume XII, No. 1 Juni 2020

teknologi komunikasi dalam mengatur sistem komunikasi bagi diri sendiri. Tujuannya kita dapat menemukan memanfaatkan perkem-bangan teknologi komunikasi ini dalam proses pengembangan keilmuan pada diri kita. Maka pengkajian ini sangat penting, supaya kita bisa memahami pada posisi dimana kita sekarang dalam memanfaatkan perkembangan teknologi komunikasi untuk mengembangkan potensi diri kita.

\section{LITERATURE REVIEW}

Adapun beberapa kajian terdahulu yang berkaitan dengan pengembangan teknologi komunikasi untuk dapat dijadikan sebagai pedoman awal dalam kajian ini antara lain hasil penelitian yang ditulis oleh Maya Sandra Rosita Dewi dengan judul Komunikasi Sosial di era industri 4.0 (Studi Pada Etika Komunikasi Remaja Perempuan Melalui Media Sosial di Era Industri 4.0). ${ }^{3}$ kajian ini menjelaskan

\footnotetext{
3 Maya Sandra Rosita Dewi, "Komunikasi Sosial di era industri 4.0 (Studi Pada Etika Komunikasi Remaja Perempuan Melalui Media Sosial di Era Industri 4.0)",
}

bahwa perkembangan teknologi komunikasi harus dibarengi dengan menerapkan etika dalam berkomunikasi dan etika bermedia. Etika komunikasi sangat penting saat berhadapan dengan media komunikasi, karena sangat berefek kepada penggunaan media tersebut. Penelitian ini menekankan bahwa etika komunikasi menjadi acuan utama dalam mengkosumsi media sosial. Disebabkan media sosial tidak memiliki batas jarak dan waktu dalam bertukar informasi. Oleh karena itu, selain melihat daripada perlunya etika dalam penggunaan teknologi komunikasi, maka disisi lain teknologi komunikasi juga memberi ruang yang sangat luas untuk menghasilkan nilai manfaat yang besar. Dengan demikian, perlunya melihat pembentukan konsep dalam pengembangan diri melalui pemanfaatan teknologi komunikasi menjadi sesuatu yang sangat penting untuk dibarengi dengan perkembangan

Research Fair Unisri, Vol. 4, No. 1, 2020, http://ejurnal.unisri.ac.id/index.php/rsfu/article /view/3388, hal. $65-77$ 
Komunike, Volume XII, No. 1 Juni 2020

saat ini.

Adapun penelitian yang seirama lainnya ditulis oleh Mohammad Zamroni dengan judul Perkembangan Teknologi komunikasi dan Dampaknya Terhadap Kehidupan. ${ }^{4}$ Penelitian ini menjelaskan bahwa revolusi teknologi komunikasi disebabkan adanya revolusi ilmu komunikasi. Memang dalam perkembangan kehidupan, refolusi teknologi mejadi satu perubahan yang tidak dapat dibendungi, namun perubahan tersebut tidak dapat terjadi apabila tidak ada perubahan dan pengembangan ilmu komunikasi yang ada pada diri manusia. Manusia sebagai pembina komunikasi dan manusia juga yang membuat perubahan komunikasi. Oleh karena itu, dalam kajian ini menegaskan bahwa perkembangan ilmu komunikasi menjadi dasar bagi terbentuknya revolusi teknologi komunikasi. Oleh karena itu, selain melaihat adanya perkembangan ilmu komunikasi, juga dalam hal ini perlu

\footnotetext{
${ }^{4}$ Mohammad Zamroni, "Perkembangan Teknologi Komunikasi dan Dampaknya Terhadap Kehidupan”, Jurnal Dakwah: Media Komunikasi dan Dakwah, Vol. 10, No. 2, 2009,
}

untuk melihan kesiapan pada diri manusia untuk menerima hakikat terjadinya perubahan teknologi komunikasi disebabkan oleh perkembangan diri manusia tersebut dalam beradaptasi dengan kehidupannya.

Oleh karena itu, kajian tentang konsep pengambangan diri dalam menghadapi perkembangan teknologi komunikasi perlu dikaji secara khusus, dengan tujuan dapat menjadi acuan dasar bagi umat manusia dalam menghadapi perubahan dan pengebangan teknologi komunikasi. Dalam hal ini, kita dapat menentukan secara pasti tentang posisi diri kita yang sebenarnya dalam perkembangan zaman teknologi komunikasi era 4.0 ini. Kesediaan penyesuaian diri di era 4.0 sangat menentukan integritas yang dimiliki oleh seseorang.

\section{METODE PENELITIAN}

Penelitian ini adalah kajian

http://ejournal.uinsuka.ac.id/dakwah/jurnaldakwah/article/view/4 $\underline{22}$, hal. $195-211$ 
Komunike, Volume XII, No. 1 Juni 2020

literatur dalam bidang komunikasi alamtologi, dengan menggunakan pendekatan grounded theory. Tujuannya untuk mengkaji tentang konsep kesiapan pengembangan diri dalam menghadapi perkembangan teknologi komunikasi di era 4.0. Adapun teknik pengumpulan data digunakan beberapa dokumen dalam bentuk literatur-literatur yang menjelaskan tentang teknologi komunikasi serta tentang konsep kesiapan diri dalam menghadapi era 4.0. Sedangkan teknik analisis data dilakukan dengan cara menggunakan pendekatan content analysis, dengan tujuan untuk menganalisis berbagai tek yang menjelaskan tentang konsep kesiapan diri dalam menghadapi perkembangan teknologi komunikasi. Oleh karena itu, penelitian ini penting dilakukan untuk menemukan dan memperkaya literatur yang mengkaji tentang perkembangan teknologi komunikasi di era 4.0.

\section{HASIL DAN PEMBAHASAN}

\section{Pengembangan Diri}

Pembahasan

tentang pengembangan diri tidak lah dipahami sebuah pembahasan yang langsung membicarakan tentang potensi keberhasilan seseorang. Namun untuk menjelaskan pembahasan tentang pengembangan diri, dalam filsafat ilmu harus memahami konsep diri. konsep diri merupakan suatu konsep yang dimiliki oleh seorang individu tentang dirinya sendiri untuk melihat pribadi secara utuh, menyangkut fisik, emosi, intelektual, sosial, spiritual serta menjadi pedoman seseorang dalam bertindak. Selain demikian konsep diri menjadi faktor yang mendorong seseorang dalam memutuskan suatu keputusan, dimana dalam diri seseorang memiliki kebutuhan, dan kepuasaan yang dimilikinya, sehingga hal ini membentuk perilaku konsumtif individu. ${ }^{5}$

Membentuk konsep diri diawali

\footnotetext{
5 Sunaryo, Psikologi Untuk keperawatan (Jakarta: Kedoteran EGC, cet. 1, 2004), hal. 32
} 
oleh sifat pengetahuan manusia dalam kehidupannya. Adapun sifat manusia dalam kehidupan ada empat macam yaitu dia tahu bahwa dirinya tahu, dia tahu bahwa dirinya tidak tahu, dia tidak tahu bahwa dirinya tahu dan dia tidak tahu bahwa dirinya tidak tahu. Dari empat sifat tersebut dituntut untuk bisa menilai dirinya sendiri berada pada posisi yang mana, sehingga dapat membentuk sikap rendah diri pada orang yang berilmu. ${ }^{6}$ Sifat rendah diri merupakan suatu keharusan bagi orang yang berilmu untuk mengembangkan diri. Disisi lain juga disebutkan "orang yang berilmu laksana padi semakin berisi semakin merunduk," hal ini bermaksud orang yang berilmu dalama melakukan pengembangan diri harus bisa mengendalikan diri dengan cara merendah diri dan tidak menjadi sombong.

${ }^{6}$ Jujun S. Suriasumantri, Filsafat Ilmu Sebuah Pengantar Populer (Jakarta: Pustaka Sinar Harapan, cet. 12, 1999), h. 19.

${ }^{7}$ Abdul Hadi, Konsep Pendidikan AlFarabi dan Ibnu Sina, Jurnal Ilmiah Sintesa,
Memahami konsep diri menjadi prioritas utama dalam membentuk pengembangan diri. Pengembangan diri tidak hanya bertumpu pada kecerdasan saja. Pengembangan terbentuk dari tiga potensi yang harus dimiliki yaitu pendidikan, membangun hubungan(jaringan) baik antar individu maupun kelompok dan pengalaman.

\section{Pendidikan}

Pendidikan adalah sebuah proses pengangkatan harkat dan martabat manusia dari posisi yang rendah kepada posisi yang selayaknya, untuk dipersiapkan dirinya dalam menghadapi masa depan yang penuh dengan tantangan, serta mengamalkan ajaran-ajarannya. ${ }^{7}$ Secara filosofis pendidikan adalah proses pengubahan sikap atau perilaku seseorang maupun kelompok untuk mendewasakan manusia melalui pengajaran dan pelatihan, yang tujuannya mengantarkan manusia kepada kecerdasan dan berilmu sesuai dengan perjenjangannya. ${ }^{8}$ Dapat dipahami

Vol. 9. No. 2, Januari 2010, (Banda Aceh: Kopertais Wilayah V Aceh, 2010) h. 14

${ }^{8}$ Sofyan Anwar Mufid, Ilmu Dakwah Ditinjau Dari Berbagai Aspeknya, Dakwah dan 
Komunike, Volume XII, No. 1 Juni 2020

pendidikan adalah sebuah proses perubahan keilmuan yang tumbuh pada manusia dari masa kebodohan kepada masa kecerdasan.

Pendidikan juga merupakan usaha sadar untuk menyiapkan peserta didik melalui kegiatan bimbingan, pengajaran, dan atau latihan bagi peranannya di masa yang akan datang. ${ }^{9}$ Menurut UU No. 20 tahun 2003 Pendidikan adalah usaha sadar dan terencana untuk mewujudkan suasana belajar dan proses pembelajaran agar peserta didik secara aktif mengembangkan potensi dirinya untuk memiliki kekuatan spiritual keagamaaan, pengendalian diri, kepribadian, kecerdasan, akhlak mulia, serta ketrampilan yang diperlukan dirinya, masyarakat, bangsa, dan Negara. Dari pembahasan tersebut dapat dipahami bahwa pendidikan adalah Bimbingan atau pertolongan yang diberikan oleh orang dewasa kepada perkembangan anak untuk

Pendidikan, (Banda Aceh: Fakultas Dakwah IAIN Ar-Raniry, 2000), h. 98

${ }^{9}$ Fadlil Yani Ainusysyam, Pendidikan Akhlak, dalam Ilmu dan Aplikasi Pendidikan

mencapai kedewasaannya dengan tujuan agar anak cukup cakap melaksanakan tugas hidupnya sendiri tidak dengan bantuan orang lain.

Adapun tujuan pendidikan adalah mencerdaskan kehidupan bangsa dan mengembangkan manusia dengan seutuhnya, yaitu manusia yang beriman dan bertaqwa terhadap Tuhan dan berbudi pekerti luhur, memiliki pengetahuan dan keterampilan, kesehatan jasmani dan rohani, kepribadian yang mantap dan mandiri serta rasa tanggung jawab kemasyarakatan dan kebangsaan. Adanya pendidikan bagi manusia, maka akan timbul dalam diri seseorang untuk berlomba-lomba dan memotivasi diri untuk lebih baik dalam segala aspek kehidupan. Pendidikan merupakan salah satu syarat untuk lebih memajukan potensi diri. Usaha pendidikan mulai dari tingkat SD sampai pendidikan di tingkat Universitas.

(tt: Imperial Bhakti Utama, Jild. 3, cet. 2, 2007), hal. 20. 
Komunike, Volume XII, No. 1 Juni 2020

Pada intinya pendidikan itu bertujuan untuk membentuk karakter seseorang yang beriman dan bertakwa kepada Tuhan. Sebagaimana dijelaskan oleh Ahmad Helwani (2018), menjelaskan tujuan utama pendidikan adalah membentuk karakter manusia ke arah yang baik. Adapun bentuk nilai kerakter tersebut meliputi nilai keimanan, birrul walidain, syukur, bijaksana dan sabar. ${ }^{10}$ Berdasarkan konsep ini peran pengembangan teknologi komunikasi dari sudut pendidikan sangat penting untuk diterapkan dalam kehidupan seharihari. Dengan demikian, perlu dipahami juga bahwa jika pada suatu negeri pendidikannya maju, maka negeri tersebut menjadi maju. Jika pada suatu negeri pendidikannya merosot, maka siap-siap negiri itu akan bangkrut. Pengembangan diri dalam pendidikan menjadi sebuah keharusan dalam kehidupan manusia.

Disisi lain menurut pemahaman

10 Ahmad Helwani Syafi`i, Muhammad Syauki, “Karakter Manusia Dalam Perspektif Al-Qur `an surat Lukman”, Jurnal penulis, pemerintahan kita ada sedikit kekhilafan dalam memaknai pendidikan. Kesuksesan pendidikan yang dipahami di Indonesia hanya menekankan pada kecerdasan menjawab dalam ujian. Hal ini bisa dibuktikan perkembangan sistim ujian nasional untuk sekolah. Dulu disebutkan ujian ebtanas dan sekarang sudah berobah menjadi UN yang kualitasnya lebih ketat dari yang dahulu, kesuksesan menjawab soal ujian tersebut dijadikan sebagai tolak ukur keberhasilan pendidikan. Sayangnya mereka tanpa melihat kesuksesan pendidikan kepada proses pembentukan karakter dan budi pekerti anak. Disini dapat disimpulkan bahwa kesuksesan yang dipahami sekarang belum mencapai hakikat dari tujuan pendidikan yaitu membentuk manusia yang beriman dan berakhlak yang mulia.

Pengembangan diri dalam pendidikan sebenarnya dimulai dari

Komunike, Vol. X, No. 2, desember 2018, https://journal.uinmataram.ac.id/index.php/ko munike/article/view/673/377, hal. 89 - 98 
Komunike, Volume XII, No. 1 Juni 2020

pendidikan dasar sampai pendidikan atas harus menguasai ilmu pengetahuan. Ketika masuk dalam perguruan tinggi pada jenjang strata satu harus memahami teori, pada strata dua memahami pengembangan teori dan pada strata tiga harus bisa menciptakan teori (ijtihad). Untuk menjadi manusia yang intelektual, selain harus menguasai proses pendidikan tersebut juga harus mempunyai sifat kritis, ramah, dan bertanggung jawab.

\section{Membangun Hubungan}

Membangun hubungan yang dimaksudkan dalam pembahasan ini merupakan membina kerja sama dengan orang lain baik secara individu maupun secara kelompok. Sebagaimana yang lazim dipahami bahwa manusia adalah kelompok sosial yang saling membutuhkan antara satu sama lain dan manusia tidak mungkin bisa hidup sendiri dengan tanpa

\footnotetext{
${ }^{11}$ Bagja Waluya, Sosiologi: Menyelami Fenomena Sosial di Masyarakat (Bandung:
}

bantuan dari orang lain. ${ }^{11}$ Berdasarkan pemahaman tersebut perlu dipahami bahwa membangun hubungan dalam kehidupan menjadi sebuah keharusan dalam pengembangan diri.

Pengembangan diri melalui membangun hubungan tidak terlepas dari sikap tolong menolong. Adapun sikap tolong menolong ada dua pembagian yaitu perilaku altruisme dan prososoial. Perilaku altruisme merupakan pemberian pertolongan kepada orang lain tanpa mengharapkan adanya keuntungan pada diri orang yang menolong. Sedangkan prososial merupakan pemberian pertolongan kepada orang lain dengan mengharapkan adanya keuntungan dari pada pihak orang yang ditolongkan. Pertolongan dalam bentuk prososial memiliki konsekuensi positif pada orang lain. Fenomena manusia sekarang ini sikap tolong menolong yang digunakan lebih banyak menggunakan tolong menolong dalam

Setia Punama Inves, jild. 2, cet. 1, 2007), hal. 86. 
Komunike, Volume XII, No. 1 Juni 2020

bentuk prososial. ${ }^{12}$

Perkembangan dari tolong menolong akan membangun sifat kerja sama. Sifat kerja sama dalam konsep pengembangan diri sangat dibutuhkan oleh seseorang yang berfikir secara positif. Sifat kerja sama merupakan orang-orang yang terlibat sama-sama mendapatkan keuntungan dari perilaku tersebut. Hubungan ini disebut hubungan yang mutualis. Dari pembahasan tersebut dapat dipahami bakwa kerja sama merupakan perilaku pada beberapa orang sekaligus dengan melakukan dan menempuh jalan yang sama dan berusaha untuk mencapai tujuan bersama. Namun sebalik demikian ada juga orang melakukan kerja sama dan tidak menempuh jalan kerja sama sehingga masing-masing saling berusahan untuk lebih cepat mencapai tujuan. Pola ini disebut kompetisi bukan kerja sama.

Pengembangan diri melalui pembentukan hubungan sangat

${ }^{12}$ Faturochman, Pengantar Psikologi Sosial (Yogyakarta: Pinus, cet. 2, 2009), h. 74. dituntut memiliki sifat rendah diri dan ramah dengan yang lainnya. Dengan adanya dua macam sifat ini dalam membentukkan hubungan akan terbentuk kepribadian sifat saling menghargai. Sifat saling menghargai merupakan sebuah sifat yang harus dilaksanakan dalam membangun hubungan. Membangun hubungan menjadi alat utama bagi intelektual dalam mengembangkan ilmunya. Hal ini disebabkan pengembangan ilmu harus dilakukan dengan hubungan dan kerja sama yang baik. Maka hubungan baik akan dinilai orang baik dan hubungan yang tidak baik akan dinilai orang tidak baik.

\section{Pengalaman}

Pengalaman ialah hasil persentuhan alam dengan panca indra manusia. Berasal dari kata peng-alaman. Pengalaman memungkinkan seseorang menjadi tahu dan hasil tahu ini kemudian disebut pengetahuan. ${ }^{13}$ Dalam dunia kerja istilah pengalaman

\footnotetext{
13 Dani Vardiansyah, Filsafat IImu Komunikasi: Suatu Pengantar, (Jakarta: Indeks,2008), hal.3
} 
Komunike, Volume XII, No. 1 Juni 2020

juga digunakan untuk merujuk pada pengetahuan dan ketrampilan tentang sesuatu yang diperoleh lewat keterlibatan atau berkaitan dengannya selama periode tertentu. Secara umum, pengalaman menunjuk kepada mengetahui bagaimana atau pengetahuan prosedural, daripada pengetahuan proposisional. Pengetahuan yang berdasarkan pengalaman juga diketahui sebagai pengetahuan empirikal atau pengetahuan posteriori. Seorang dengan cukup banyak pengalaman di bidang tertentu dipanggil ahli.

Pandangan terhadap diri tentang kesuksesan sangat dipengaruhi oleh pengalaman keberhasilan dan kegagalan. Pengalaman keberhasilan dan kegagalan sudah mulai sejak masa kecil dan akan tetap terjadi selama masa hidup. Pengalaman kegagalan dapat merugikan perkembangan harga dir dan gambaran diri yang baik. Namun semua orang selulu menghindari dari pengalaman yang

\footnotetext{
${ }^{14}$ Paul J. Centi, Mengapa Rendah
} Diri? (ttt, tth), hal. 23 gagal. ${ }^{14}$ Perlu dipahami pengalaman dalam pengembangan konsep diri bukanlah sebuah warisan atau ditentukan secara biologis. Namun pengembangan diri sangat dipengaruhi oleh pengalaman-pengalaman dalam kehidupan, baik pengalaman pada diri sendiri maupun pengalaman pada orang lain.

Konsep pengembangan diri melalui pengalaman perlu diperhatikan. Dengan adanya belajar dari pengalaman akan menumbuhkan sikap bertanggung jawab. Sikap bertanggung jawab mengarakhan hidup manusia kepada sifat takwa, jujur, amanah. Manusia yang menyadari dirinya mukallaf disebut manusia bertanggung jawab atas penggunaan segalam keistemewaannya. Manusia dijadikan khalifah di muka bumi sebagai bentuk tugas yang harus bertanggung jawab terhadap amanah yang telah ditugaskan oleh sang khaliq untuk 
Komunike, Volume XII, No. 1 Juni 2020

membawa misi-misi islam. ${ }^{15}$

\section{Perkembangan Teknologi Komunikasi}

Sebagaimana pembahasan

sebelumnya bahwa manusia adalah makhluk sosial. Sebagai makhluk sosial, manusia tidak mungkin bisa lepas dari manusia satu dengan manusia lainnya. Itu artinya, manusia tidak mungkin bisa berdiri sendiri. Manusia memerlukan beragam informasi untuk dapat menjalani hidup lebih baik dari sebelumnya, dan manusia juga perlu menjalin suatu hubungan dengan manusia lain demi tercapainya kebahagiaan, kesejahteraan. Dari apa yang kita lakukan akan tersirat sebuah pesan untuk diri kita sendiri maupun orang lain. oleh karena itu, komunikasi tidak akan pernah bisa terlepas dari kehidupan seseorang. Perkembangan teknologi komunikasi tak akan pernah bisa berhenti. Perkembangan ini terjadi

15 M. Abdul Mujieb, Ensiklopedia Tasawuf Imam Al-Ghazali (Jakarta Selatan: Mizan Publika, cet. 1, 2009), hal. 291

16 Sadu Wasistiono, “Pentingnya Komunikasi Pemerintah Untuk Membangun sejak zaman dahulu hingga saat ini. Dalam pembahasan ini akan menjelaskan perkembangan teknologi komuniksasi dari masa ke masa.

$$
\text { Perkembangan teknologi }
$$

komunikasi telah semakin

mendekatkan kita pada batas kemampuan perangkat intelektual menghadapi kompleksitas keadaan sekarang ini. Penekanan yang lebih besar bagi penggunaan teknologi informasi untuk membangun dan mengembangkan kebersamaan serta saling pengertian atas manusia. Masalah yang timbul adalah manusia memiliki kecenderungan untuk menilai komunikasi sebagai suatu yang sederhana, sebenarnya tidak sederhana. ${ }^{16}$ Hal ini memicu untuk pentingnya memahami perkembangan teknologi komunikasi dalam kehidupan kita.

Kebersamaan dan Kepercayaan”, Jurnal Komunika: Warta Ilmiah Populer Komunikasi Dalam Pembangunan, Vol. 8, Nomor, 2, 2005, hal. 7. 
Komunike, Volume XII, No. 1 Juni 2020

\section{Sejarah Perkembangan Teknologi}

\section{Komunikasi}

Perkembangan peradaban manusia diiringi dengan perkembangan cara penyampaian informasi (yang selanjutnya dikenal dengan istilah teknologi informasi), mulai dari gambar-gambar yang tak bermakna di dinding-dinding gua, peletakan tonggak sejarah dalam bentuk prasasti, sampai diperkenalkannya dunia arus informasi yang dikenal dengan nama internet.

a. Masa Prasejarah

Pada zaman ini, teknologi informasi dan komunikasi yang dilakukan oleh manusia berfungsi sebagai sistem untuk pengenalan bentuk-bentuk yang manusia kenal. Untuk menggambarkan informasi yang diperoleh, mereka menggambarkannya pada dinding-dinding gua tentang berburu dan binatang buruannya. Pada masa ini, manusia mulai mengidentifikasi benda-benda yang ada di sekitar lingkungan tempat tinggal mereka, kemudian melukiskannya pada dinding gua tempat tinggalnya. Awal komunikasi mereka pada zaman ini hanya berkisar pada bentuk suara dengusan dan menggunakan isyarat tangan. Pada zaman prasejarah mulai diciptakan dan digunakan alat-alat yang menghasilkan bunyi dan isyarat, seperti gendang, terompet yang terbuat dari tanduk binatang, dan isyarat asap sebagai alat pemberi peringatan terhadap bahaya.

Adapun masa prasejarah dibagi beberapa masa, sebagaimana yang dibenutkan berikut:

3000 SM. Masa ini untuk yang pertama kali, tulisan digunakan oleh bangsa Sumeria dengan menggunakan simbol-simbol yang dibentuk dari piktografi sebagai huruf. Simbol atau huruf-huruf ini juga mempunyai bentuk bunyi (penyebutan) yang berbeda sehingga mampu menjadi kata, kalimat, dan bahasa.

2900 SM. Pada masa ini bangsa Mesir Kuno menggunakan huruf hieroglif. Hieroglif merupakan bahasa simbol, dimana setiap ungkapan diwakili oleh simbol yang berbeda. Jika simbol-simbol tersebut digabungkan menjadi satu rangkaian, maka akan 
Komunike, Volume XII, No. 1 Juni 2020

menghasilkan sebuah arti yang berbeda. Bentuk tulisan dan bahasa hieroglif ini lebih maju dibandingkan dengan tulisan bangsa Sumeria.

500 SM. Pada 500 SM, manusia sudah mengenal cara membuat serat dari pohon papyrus yang tumbuh di sekitar sungai Nil. Serat papyrus dapat digunakan sebagai kertas. Kertas yang terbuat dari serat pohon papyrus menjadi media untuk menulis atau media untuk menyampaikan informasi yang lebih kuat dan fleksibel dibandingkan dengan lempengan tanah liat yang sebelumnya juga digunakan sebagai media informasi.

105 M. Pada masa ini, bangsa Cina berhasil menemukan kertas. Kertas yang ditemukan oleh bangsa Cina pada masa ini adalah kertas yang kita kenal sekarang. Kertas ini dibuat dari serat bambu yang dihaluskan, disaring, dicuci, kemudian diratakan dan dikeringkan. Penemuan ini juga memungkinkan sistem pencetakan yang dilakukan dengan menggunakan blok kayu yang ditoreh dan dilumuri oleh tinta atau yang kita kenal sekarang dengan sistem cap. ${ }^{17}$

b. Masa Modern (1400 M s.d. Sekarang)

$$
\text { Perkembangan teknologi }
$$

komunikasi pada masa modern ini terbagi kepada beberapa fase, sebagaimana disebutkan dalam pembahasan berikut ini:

Tahun 1455. Pada tahun ini untuk pertama kalinya Johann Gutenberg mengembangkan mesin cetak dengan menggunakan plat huruf yang terbuat dari besi dan dapat diganti-ganti dalam bingkai yang terbuat dari kayu.

Tahun 1830. Augusta Lady Byron menulis program komputer yang pertama di dunia. Ia bekerja sama dengan Charles Babbage menggunakan mesin analyticalyang didesain sehingga mampu memasukkan data, mengolah data, dan menghasilkan bentuk

17 Y. Maryono, Teknologi Informasi dan Komunikasi (Jakarta: Yudhistira, cet. 1, 2008), hal. 19 
keluaran dalam sebuah kartu. Mesin ini dikenal sebagai bentuk komputer digital yang pertama, walaupun cara kerjanya lebih bersifat mekanis daripada bersifat digital.

Tahun 1837. Samuel Morse mengembangkan telegraf dan bahasa kode morse bersama Sir William Cook dan Sir Charles Wheatstone. Morse menggunakan kode-kode sederhana untuk mewakili pesan-pesan yang ingin dikirimkan dengan menggunakan pulsa listrik melalui kabel tunggal. Namun sinyal-sinyal yang dapat dikirim dengan baik hanya berada dalam jarak $32 \mathrm{~km}$. Untuk jarak yang lebih jauh, sinyalsinyal yang diterima menjadi terlalu lemah untuk direkam. Kemudian, Morse membangun peralatan relai yang ditempatkan di setiap $32 \mathrm{~km}$ dari stasiun sinyal. Relai tersebut berfungsi untuk mengulangi sinyal yang diterima dan mengirimnya kembali ke $32 \mathrm{~km}$ berikutnya. Relai terdiri dari sakelar yang dioperasikan secara elektromagnetik. Sistem telegraf kemudian segera digunakan untuk bisnis yang membutuhkan pengiriman pesan secara cepat untuk jarak yang jauh, seperti surat kabar dan pesan untuk perjalanan kereta api.

Tahun 1877. Alexander Graham Bell menciptakan dan mengembangkan telepon yang dipergunakan pertama kali secara umum. Pada 1879, sistem pemanggilan telepon mulai menggunakan nomor yang menggantikan sistem pemanggilan nama. Hal ini untuk mencegah operator yang tidak mengenal semua pelanggan. Sistem penomoran telepon menggunakan huruf dan angka, dimana nomor telepon menggunakan sistem dua huruf dan lima digit angka.

Tahun 1889. Herman Hollerith menerapkan prinsip kartu perforasi untuk melakukan penghitungan. Tugas pertamanya adalah menemukan cara yang lebih cepat untuk melakukan perhitungan bagi Biro Sensus Amerika Serikat. Sensus yang dilakukan pada 1880 membutuhkan waktu tujuh tahun untuk menyelesaikan perhitungan. Dengan berkembangnya populasi, Biro Sensus tersebut memperkirakan bahwa 
Komunike, Volume XII, No. 1 Juni 2020

dibutuhkan waktu sepuluh tahun untuk menyelesaikan perhitungan sensus. Hollerith menggunakan kartu perforasi untuk memasukkan data sensus yang kemudian diolah oleh alat tersebut secara mekanik. Sebuah kartu dapat menyimpan hingga 80 variabel. Dengan menggunakan alat tersebut, hasil sensus dapat diselesaikan dalam waktu enam minggu. Selain memiliki keuntungan dalam bidang kecepatan, kartu tersebut berfungsi sebagai media penyimpan data. Tingkat kesalahan perhitungan juga dapat ditekan secara drastis.

Tahun 1931. Vannevar Bush membuat sebuah kalkulator untuk menyelesaikan persamaan differensial. Mesin tersebut dapat menyelesaikan persamaan differensial kompleks yang selama ini dianggap rumit oleh kalangan pelajar dan mahasiswa. Mesin tersebut sangat besar dan berat karena ratusan gerigi dan poros yang dibutuhkan untuk melakukan perhitungan.

Tahun 1939. Dr. John V. Atanasoff dan dibantu oleh Clifford
Berry berhasil menciptakan komputer elektronik digital pertama. Sejak saat ini, komputer terus mengalami perkembangan sehingga menjadi semakin canggih. Mengenai sejarah perkembangan komputer ini akan dijelaskan pada bagian berikutnya. Tahun 1973 - 1990. Pada masa ini, istilah internet diperkenalkan dalam sebuah paper tentang TCP/IP. Secara harfiah, internet (interconnected networking) diartikan sebagai rangkaian komputer yang terhubung di dalam beberapa rangkaian. Rangkaian pusat yang membentuk internet diawali pada 1969 sebagai ARPANET yang dibangun oleh ARPA (United States Department of Defense Advanced Research Projects Agency). Beberapa penyelidikan awal yang disumbang oleh ARPANET di antaranya adalah kaedah rangkaian tanpa pusat (decentralised network), teori queueing, dan kaedah pertukaran paket (packet switching). Namun pada tahun 1981, National Science Foundation mengembangkan backbone yang disebut CSNET dengan kapasitas 
Komunike, Volume XII, No. 1 Juni 2020

56 Kbps untuk setiap institusi dalam pemerintahan. Adapun pada 1 Januari 1983, ARPANET menukar protokol rangkaian pusatnya, dari NCP ke TCP/IP. Ini merupakan awal dari Internet yang kita kenal sekarang. Kemudian pada 1986, IETF mengembangkan sebuah server yang berfungsi sebagai alat koordinasi di antara DARPA, ARPANET, DDN, dan Internet Gateway. Pada 1990-an, internet telah berkembang dan menyambungkan banyak pengguna jaringan-jaringan komputer yang ada. ${ }^{18}$

Tahun 1991 - Sekarang. Sistem bisnis dalam bidang IT pertama kali terjadi ketika CERN memungut bayaran dari para anggotanya untuk menanggulangi biaya operasionalnya. Pada 1992, mulai terbentuk komunitas internet dan diperkenalkannya istilah World Wide Web (www) oleh CERN. Pada 1993, NSF membentuk InterNIC untuk menyediakan jasa pelayanan internet menyangkut direktori dan

${ }^{18}$ Wahyono, Teguh. Etika Komputer dan Tanggung Jawab Profesional di Bidang penyimpanan data serta database (oleh AT\&T), jasa registrasi (oleh Network Solution Inc), dan jasa informasi (oleh General Atomics/CERFnet). Pada 1994, pertumbuhan internet melaju dengan sangat cepat dan mulai merambah ke dalam berbagai segi kehidupan manusia dan menjadi bagian yang tidak dapat dipisahkan dari manusia. Pada 1995, perusahaan umum mulai diperkenankan menjadi provider dengan membeli jaringan di backbone. Langkah ini memulai pengembangan teknologi informasi, khususnya internet dan penelitianpenelitian untuk mengembangkan sistem dan alat yang lebih canggih. ${ }^{19}$

\section{Penyesuaian Diri Untuk Menghadapi Perkembangan Teknologi Komunikasi}

Kehidupan sekarang yang tampaknya makin kecil, perkembangan teknologi komunikasi sangat memudahkan kita untuk menemukan informasi melintasi batas-batas dunia,

Teknologi Informasi. (Yogyakarta:ANDI 2009). h 134

${ }^{19}$ Y. Maryono, Teknologi..., hal. 23 
Komunike, Volume XII, No. 1 Juni 2020

bukan hanya batas geografis, tetapi juga batas social maupun psikologis.

Oleh karena itu, teknologi baru tidak saja memudahkan orang melintas budaya, namun membawa dampak terhadap ketidak tahuan menggunakan teknologi itu sendiri. Supaya menjadi efektif dalam menggunakan teknologi maka tidak ada jalan lain, kecuali menguasai teknologi komunikasi.

Teknologi komunikasi telah membawakan kita semakin dekat dalam kebersamaan menjadi kedekatan fisik. Perkembangan teknologi juga membiarkan kita memahami perkembangan budaya yang lain dan kita tidak terpaku dalam satu budaya saja yaitu budaya kita sendiri. Dalam hal ini kita bisa mengembangkan relasi social yang semakin kompleks. ${ }^{20}$

Perkembangan komunikasi sekarang ini mengalami kemajuan yang sangat pesat karena didukung oleh teknologi komunikasi. Dalam hal ini dapat dipahami teknologi komunikasi sebagai semua perkembangan teknik yang mengubah, memajukan, mempercepat dan mempercanggih proses kerja komunikasi. Dia mengubah cara bekerja komunikator, cara bekerja pengiriman pesan, cara kerja media, cara audiens menerima pesan dan cara pengembalian dampak.

Dengan adanya bantuan perkembangan teknologi komunikasi, manusia semakin mudah berkomunikasi tanpa batas ruang budaya yang tegas. Oleh karena itu generasi kita agar disiapkan lebih awal untuk mempelajari cara penggunaan teknologi sehingga mereka tidak kaget menghadapi informasi yang disodorkan dengan bantuan teknologi. Selanjutnya harus siap mempelajari kebudayaan lain yang dikembangkan melalui teknologi informasi.

${ }^{20}$ Alo Liliweri, Makna Budaya Dalam Komunikasi Antar Budaya (Yogyakarta: Lkis Pelangi Aksara, cet. 2, 2007), hal. 42. 


\section{KESIMPULAN}

Berdasarkan pembahasan yang telah dijelaskan diatas mengenai pengembangan diri dalam menghadapi perkembangan teknologi komunikasi, maka dapat disimpulkan bahwa pengembangan diri merupakan sebuah proses yang dilakukan oleh manusia untuk membentuk dan mengembangkan potensi diri manusia berdasarkan menggunakan pendidikan, membangun jaringan sosial dan pengalaman hidup.

Perkembangan teknologi komunikasi merupakan suatu perkembangan global yang tidak bisa dibendungi atau diantisipasi. Manusia perlu melakukan penysuaian diri terhadap perkembangan teknologi tersebut. Penyesuaian diri terhadap perkembangan teknologi komunikasi sedah menjadi perkembangan budaya dalam praktek komunikasi. Terkembangan teknologi komunikasi diawalai para periode komunikasi tulisan pada masa pra sejarah sampaik perkembangan komunikasi elektronik pada masa modern.
Pengembangan diri dalam menghadapi perkembangan teknologi komunikasi menjadi keharusan bagi semua orang untuk menyesuaikan diri dalam perkembangan budaya bermasyarakat. Penyesuaian diri dengan teknologi komunikasi era 4.0 pada posisi sebagai konsumen yaitu menghantarkan kita kepada jalan yang lebih mudah dan praktis dalam melakukan komunikasi dan akses informasi yang cepat, seperti manfaat internet, manfaat hanphone, televise dan lain sebagainya.

\section{DAFTAR PUSTAKA}

Ahmad Helwani Syafi`i, Muhammad Syauki, "Karakter Manusia Dalam Perspektif Al-Qur'an surat Lukman”, Jurnal Komunike, Vol. X, No. 2, Desember 2018, https://journal.uinmataram.ac.i d/index.php/komunike/article/vi ew/673/377,

Ainusysyam, Fadlil Yani, Pendidikan Akhlak, dalam Ilmu dan Aplikasi Pendidikan, tt: Imperial Bhakti Utama, Jild. 3, cet. 2, 2007. 
Komunike, Volume XII, No. 1 Juni 2020

Centi, Paul J, Mengapa Rendah Diri?, ttt, tth.

Faturochman, Pengantar Psikologi Sosial, (Yogyakarta: Pinus, cet. 2, 2009).

Hadi, Abdul, Konsep Pendidikan AlFarabi dan Ibnu Sina, (Jurnal Ilmiah Sintesa, Vol. 9. No. 2, Januari 2010)

Liliweri, Alo, Makna Budaya Dalam Komunikasi Antar Budaya, (Yogyakarta: Lkis Pelangi Aksara, cet. 2, 2007).

Maya Sandra Rosita Dewi, "Komunikasi Sosial di era industri 4.0 (Studi Pada Etika Komunikasi Remaja Perempuan Melalui Media Sosial di Era Industri 4.0)", Research Fair Unisri, Vol. 4, No. $\quad$ 2020, http://ejurnal.unisri.ac.id/index. $\mathrm{php} / \mathrm{rsfu} / \mathrm{article} / \mathrm{view} / 3388$,

Maryono, Y, Teknologi Informasi dan Komunikasi, (Jakarta: Yudhistira, cet. 1, 2008).

Mohammad Zamroni, "Perkembangan Teknologi Komunikasi dan Dampaknya Terhadap

Kehidupan”, Jurnal Dakwah: Media Komunikasi dan Dakwah, Vol. 10, No. 2, 2009, http://ejournal.uin- suka.ac.id/dakwah/jurnaldakwa

h/article/view/422,

Mufid, Sofyan Anwar, Ilmu Dakwah Ditinjau Dari Berbagai Aspeknya, Dakwah dan Pendidikan, (Banda Aceh: Fakultas Dakwah IAIN ArRaniry, 2000).

Muhammad Aminullah, Theory of Alamin: A Formation of Universal Communication Formula, Budapest International Research and Critics Institute-Journal (BIRCI-Journal) Volume 1 No. 2, June 2018 , (www.bircujournal.com/index.php (birci )

Muhammad Aminullah, Etika Komunikasi Dalam Al-Qur'an (Studi Pendekatan Tafsir Tematik Terhadap Kata AsSsidqu), Jurnal Al-Bayan Media Kajian dan Pengembangan Ilmu Dakwah, Vol. 25, Nomor 1 Januari - Juni 2019), https://www.jurnal.arraniry.ac.id/index.php/bayan/ar ticle/view/5274/3757.

Muhammad Aminullah, Komunikasi Alamtologi - ALAMIN, Jilid I, (Kuala Lumpur: Nature Pattern Resources Sdn. Bhd, Cet. 1, 2018)

Mujieb, M. Abdul, Ensiklopedia Tasawuf Imam Al-Ghazali, 
Komunike, Volume XII, No. 1 Juni 2020

(Jakarta Selatan: Mizan Vardiansyah, Dani, Filsafat Ilmu Publika, cet. 1, 2009).

Sunaryo, Psikologi Untuk keperawatan, (Jakarta: Kedoteran EGC, cet. 1, 2004).

Suriasumantri, Jujun S, Filsafat Ilmu Sebuah Pengantar Populer, (Jakarta: Pustaka Sinar Harapan, cet. 12, 1999).

Teguh, Wahyono, Etika Komputer dan Tangoung Jawab Profesional di Bidang Teknologi Informasi. Yogyakarta: ANDI 2009.

\begin{abstract}
Komunikasi: Suatu Pengantar, Jakarta: Indeks,2008.

Waluya, Bagja, Sosiologi: Menyelami Fenomena Sosial di Masyarakat, Bandung: Setia Punama Inves, jild. 2, cet. 1, 2007.

Wasistiono, Sadu, Pentingnya Komunikasi Pemerintah Untuk Membangun Kebersamaan dan Kepercayaan, (Jurnal Komunika: Warta Ilmiah Populer Komunikasi Dalam Pembangunan, Jakarta: Lipi,
\end{abstract} Vol. 8, Nomor, 2, 2005). 